Original Paper

\title{
Pendampingan Penyusunan Proposal PTK untuk Meningkatkan Profesionalisme Guru di SMA Negeri 2 Gerung
}

\author{
Hikmawati $^{*}$, Joni Rokhmat ${ }^{1}$, Kosim $^{1}$, Sutrio ${ }^{1}$ \\ ${ }^{1}$ Program Studi Pendidikan Fisika, FKIP Universitas Mataram, Mataram, NTB, Indonesia
}

\author{
*Corresponding Author: \\ Hikmawati, Program Studi \\ Pendidikan Fisika, FKIP \\ Universitas Mataram, \\ Mataram, NTB, Indonesia; \\ Email: \\ hikmawati@unram.ac.id
}

\begin{abstract}
Tujuan kegiatan pengabdian kepada masyarakat ini adalah melakukan pendampingan penyusunan Proposal Penelitian Tindakan Kelas (PTK) untuk meningkatkan profesionalisme guru di SMA Negeri 2 Gerung. Pelaksanaan kegiatan pendampingan dilakukan pada Kamis, 18 Juli 2019 yang bertempat di Ruang Laboratorium Biologi SMA Negeri 2 Gerung. Peserta kegiatan pendampingan berjumlah 26 orang guru. Metode pelaksanaan kegiatan pengabdian ini terdiri atas 4 tahap: pertama, ceramah tentang Proposal PTK; kedua, tanya jawab tentang Proposal PTK; ketiga, pendampingan menyusun proposal PTK; dan keempat, evaluasi kegiatan. Pada saat kegiatan pendampingan, peserta difasilitasi dengan menggunakan Lembar Kerja dalam menyusun Proposal PTK. Kegiatan pendampingan ini telah menghasilkan $11 \mathrm{draf}$ Proposal PTK yang siap untuk dikembangkan menjadi Proposal PTK. Berdasarkan Lembar Evaluasi Kegiatan Pendampingan diperoleh informasi bahwa: guru-guru memiliki pengetahuan yang lebih tentang penyusunan Proposal PTK sehingga lebih mudah bagi guru dalam menyusun draf Proposal PTK; kegiatan pengabdian kepada masyarakat dalam bentuk pendampingan telah mampu menghasilkan produk draf Proposal PTK; kegiatan pengabdian ini telah memberikan motivasi bagi guru dalam menyusun Proposal PTK; pendampingan penyusunan Proposal PTK membantu guru mempermudah langkah untuk pengusulan kenaikan pangkat. Dengan demikian, kegiatan pendampingan penyusunan proposal PTK ini telah meningkatkan kompetensi profesionalisme guru di SMA Negeri 2 Gerung.
\end{abstract}

Kata Kunci: Proposal; PTK; Profesionalisme

\section{Pendahuluan}

Peraturan Menteri Pendidikan Nasional Nomor 35 Tahun 2010 tentang Petunjuk Teknis Pelaksanaan Jabatan Fungsional Guru dan Angka Kreditnya menjelaskan bahwa jenjang jabatan, pangkat, dan golongan ruang guru, serta persyaratan angka kredit kumulatif minimal untuk kenaikan pangkat/jabatan setingkat lebih tinggi bagi setiap jabatan guru dari yang terendah sampai dengan yang tertinggi.

Dalam peraturan tersebut juga dijelaskan bahwa jabatan fungsional guru adalah jabatan fungsional yang mempunyai ruang lingkup, tugas, tanggung jawab, dan wewenang untuk melakukan kegiatan mendidik, mengajar, membimbing, mengarahkan, melatih, menilai, dan mengevaluasi peserta didik pada pendidikan anak usia dini jalur pendidikan formal, pendidikan dasar, dan pendidikan menengah sesuai dengan peraturan perundang-undangan yang diduduki oleh Pegawai Negeri Sipil (PNS). Guru adalah pendidik profesional dengan tugas utama mendidik, mengajar, membimbing, mengarahkan, melatih, menilai, dan mengevaluasi peserta didik pada pendidikan anak usia dini jalur pendidikan formal, pendidikan dasar, dan pendidikan menengah.

Berdasarkan Peraturan Menteri Negara Pendayagunaan Aparatur Negara dan Reformasi Birokrasi Nomor 16 Tahun 2009 tentang Jabatan Fungsional Guru dan Angka Kreditnya yang dimaksudkan pengembangan keprofesian 
berkelanjutan adalah pengembangan kompetensi guru yang dilaksanakan sesuai dengan kebutuhan, bertahap, berkelanjutan untuk meningkatkan profesionalitasnya. Guru Pertama dengan pangkat Penata Muda golongan ruang III/a sampai dengan Guru Utama dengan pangkat Pembina Utama golongan ruang IV/e wajib melaksanakan kegiatan pengembangan keprofesian berkelanjutan, yaitu pengembangan diri, publikasi ilmiah, dan/atau pengembangan karya inovatif.

SMAN 2 Gerung merupakan salah satu satuan pendidikan di Kabupaten Lombok Barat dengan tingkat publikasi ilmiah sebesar 16\%. SMAN 2 Gerung berlokasi di Jln. Imam Bonjol No.1, Gerung, Kecamatan Gerung, Kabupaten Lombok Barat. Berdasarkan hasil observasi awal ke sekolah diperoleh informasi bahwa jumlah guru di SMAN 2 Gerung sebesar 35 orang, terdiri atas 19 orang guru tetap (PNS) dan 16 orang Guru Tidak Tetap (GTT). Guru PNS tersebut memiliki sebaran golongan ruang IV/b yaitu 3 orang, IV/a sebanyak 4 orang, III/d sebanyak 1 orang, dan III/c sebanyak 11 orang. Guru yang pernah menghasilkan karya tulis ilmiah dan publikasi melalui jurnal hanya 3 orang saja, yaitu guru dengan golongan ruang IV/b. Dengan demikian, diperlukan upaya untuk meningkatkan publikasi ilmiah sebagai salah satu bentuk pengembangan keprofesian berkelanjutan (PKB) sehingga memudahkan guru untuk mengajukan kenaikan jabatan fungsional, pangkat dan golongan ruang, ke tingkat yang lebih tinggi.

Dari hasil wawancara dengan Guru dan Kepala Sekolah di SMAN 2 Gerung didapatkan informasi permasalahan yaitu guru-guru tersebut masih banyak yang mengeluhkan bagaimana cara menyusun karya tulis ilmiah, terutama cara menyusun Proposal dan Pelaksanaan Penelitian Tindakan Kelas (PTK). Pada saat wawancara, banyak guru yang meminta contoh proposal PTK, serta instrumen penelitian yang diperlukan saat melaksanakan PTK. Guru-guru tersebut juga berharap untuk didampingi oleh dosen saat pelaksanaan PTK di Kelas masing-masing agar dapat melaksanakan PTK dengan baik. Masalah lain yang dikeluhkan oleh para guru adalah bagaimana cara menghasilkan artikel ilmiah dari hasil pelaksanaan PTK sehingga dapat dipublikasi pada Jurnal.

Berdasarkan analisis situasi dan permasalahan yang dialami oleh guru-guru di SMAN 2 Gerung, maka diperlukan upaya dari berbagai pihak untuk memberikan solusi permasalahan termasuk Perguruan Tinggi. Salah satu alternatif yang dapat dilakukan untuk mengatasi permasalahan guru tersebut adalah dengan melakukan pendampingan dalam penyusunan Proposal PTK.

Target yang ingin dicapai dari kegiatan pendampingan ini adalah guru-guru SMAN 2 Gerung dapat menyusun draf Proposal PTK sebagai langkah awal untuk perencanaan pelaksanaan PTK. Dengan demikian, tingkat publikasi ilmiah di SMAN 2 Gerung sebagai salah satu bentuk pengembangan keprofesian berkelanjutan (PKB) diharapkan dapat meningkat sehingga memudahkan guru untuk mengajukan kenaikan jabatan fungsional, pangkat dan golongan ruang, ke tingkat yang lebih tinggi.

\section{Metode Pelaksanaan}

Metode pelaksanaan kegiatan pengabdian ini terdiri atas 4 tahap, dengan rincian sebagai berikut:

1. Ceramah tentang PTK

Tim pengabdian kepada masyarakat memberikan materi tentang PTK yaitu: Konsep Dasar PTK, Manfaat PTK, Perbedaan PTK dan Non PTK, Tahapan PTK, Langkah-langkah penyusunan proposal PTK, dan Sistematika proposal PTK.

2. Tanya jawab tentang Proposal PTK

Pada tahap ini peserta kegiatan diberikan kesempatan untuk bertanya tentang hal-hal yang belum dipahami dalam menyusun Proposal PTK.

3. Pendampingan menyusun proposal PTK

Kegiatan pada tahap ketiga ini dilakukan dengan cara pembimbingan dalam menyelesaikan tugas-tugas yang terdapat pada Lembar Kerja. Lembar Kerja dimaksud terdiri atas 10 tugas yaitu:

Tugas 1: Tulis salah satu masalah dalam pembelajaran di Kelas Anda dan kajilah sumber masalahnya!

Tugas 2: Tulis salah satu masalah dalam pembelajaran di Kelas Anda dan kajilah sumber masalahnya!

Tugas 3: Dengan menggabungkan hasil kegiatan Tugas 1 \& 2, rumuskan masalah Penelitian Anda!

Tugas 4: Buatlah judul PTK (tidak lebih dari 20 kata, menggambarkan variabel harapan, variabel tindakan dan setting penelitian)! 
Tugas 5: Rumuskan hipotesa tindakan!

Tugas 6: Dari permasalahan yang diangkat, rumuskan manfaat hasil penelitian!

Tugas 7: Dengan menganalisis judul penelitian, tulislah point-point dalam tinjauan pustaka!

Tugas 8: Buatlah perencanaan tindakan (seting, faktor yang diteliti, rencana tindakan berbentuk siklus terdiri dari perencanaan, tindakan, dst., jenis dan sumber data, instrument)!

Tugas 9: Tentukan cara menganalisis data yang telah dikumpulkan!

Tugas 10: Dengan memperhatikan berbagai komponen yang menentukan keberhasilan belajar, tentukan indikator kinerja penelitian Anda!

4. Evaluasi kegiatan

Evaluasi kegiatan pendampingan penyusunan Proposal PTK ini berupa komentar peserta terhadap kegiatan yang dapat diungkapkan ke dalam aspek positif dan aspek negatif, serta saran-saran untuk perbaikan di masa mendatang.

\section{Hasil dan Pembahasan}

Proposal PTK telah dilaksanakan pada Kamis, 18 Juli 2019, bertempat di Ruang Laboratorium Biologi SMA Negeri 2 Gerung. Kegiatan ini diikuti oleh 26 guru yang berasal dari berbagai mata pelajaran yaitu: Fisika, Bahasa Inggris, Sosiologi, PAI, Seni Budaya, PPKn, Matematika, Ekonomi, Kimia, Bahasa Indonesia, Biologi, BK, dan Sejarah. Materi yang diberikan tentang PTK yaitu: Konsep Dasar PTK, Manfaat PTK, Perbedaan PTK dan Non PTK, Tahapan PTK, Langkah-langkah penyusunan proposal PTK, dan Sistematika proposal PTK.

Penelitian Tindakan Kelas (PTK) merupakan suatu bentuk penelitian yang bersifat reflektif dengan melakukan tindakan tertentu untuk memperbaiki dan/atau meningkatkan praktek pembelajaran. Kegitan ini merupakan suatu bentuk penelitian, yang harus mengikuti prosedur ilmiah dalam perencanaan, pelaksanaan dan analisisnya. Permasalahan yang dikaji adalah permasalahan guru itu sendiri melalui hasil refleksi; dan tujuan akhir dari penelitian ini adalah untuk memperbaiki praktek pembelajaran di kelas.

PTK merupakan jenis penelitian kualitatifdeskriptive yang melibatkan guru sebagai pengajar sekaligus sebagai peneliti dengan menitik beratkan pada penyelesaian permasalahan pembelajaran yang dialami sehari-hari. Akhir-akhir ini PTK semakin mendapat perhatian para pakar dan praktisi pendidikan baik di negara maju maupun negara berkembang. Jenis penelitian ini telah dirasakan mampu menawarkan pendekatan dan prosedur baru yang lebih berdampak langsung dalam bentuk perbaikan dan peningkatan profesionalisme guru dalam pengelolaan pembelajaran di kelas dan atau peningkatan berbagai program sekolah (Sujana \& Muntari, 2012).

Penelitian Tindakan Kelas (PTK) adalah suatu penelitian tindakan yang dilakukan oleh guru sekaligus sebagai peneliti di kelasnya atau bersamasama dengan orang lain (kolaborasi) dengan jalan merancang, melaksanakan, dan merefleksikan tindakan secara kolaboratif dan partisipatif yang bertujuan untuk memperbaiki dan meningkatkan mutu (kualitas) proses pembelajaran di kelas melalui suatu tindakan (treatment) tertentu dalam suatu siklus (Kusnandar, 2008). Prosedur yang dilakukan dalam PTK ini ditunjukkan pada Gambar 1.

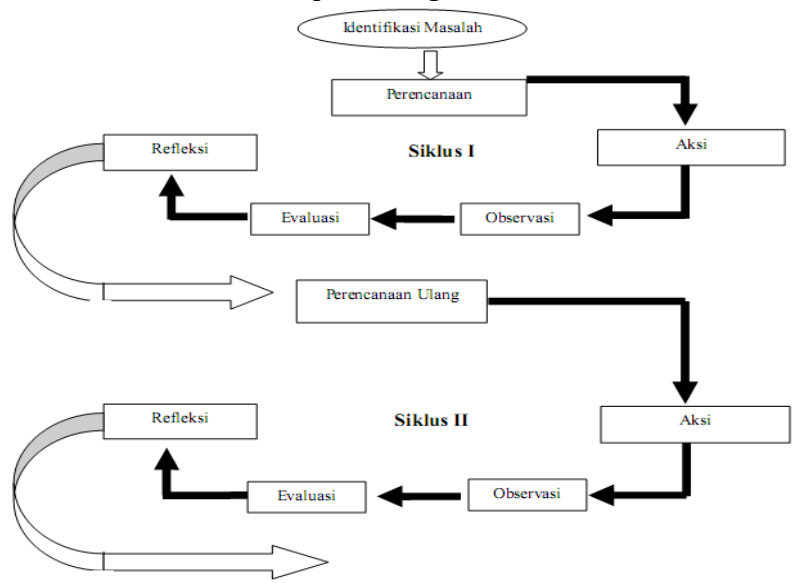

Gambar 1. Prosedur pelaksanaan PTK

Penelitian tindakan merupakan penelitian yang diarahakan untuk memecahkan masalah atau perbaikan (Aries, 2010). Seperti yang terlihat pada bagan tersebut, bahwa penelitian ini diawali dengan mengidentifikasi suatu permasalahan secara sistematis. Hasil identifikasi ini kemudian dijadikan dasar untuk merencanakan solusi dari masalah tersebut. Dalam proses pelaksanaan rencana yang telah disusun, kemudian dilakukan suatu observasi dan evaluasi yang hasilnya dipakai sebagai masukan untuk melakukan refleksi atas apa yang terjadi pada tahapan pelaksanaan (Aqib, 2009).

Apabila dari hasil refleksi menunjukkan bahwa tindakan yang telah dilakukan sudah 
memberikan hasil yang positif atau membawa perbaikan, maka penelitian dapat dihentikan. Hal ini berarti penelitian tindakan yang dilakukan hanya membutuhkan satu siklus atau mono-cycle (Aries, 2010). Akan tetapi, jika tindakan yang telah dilakukan belum memberikan hasil yang diharapkan, maka hasil refleksi tersebut digunakan sebagai landasan dalam upaya perbaikan dan penyempurnaan rencana tindakan berikutnya. Hal ini berarti penelitian tindakan yang dilakukan membutuhkan dua siklus atau lebih (multi-cycle) (Aries, 2010). Tahapan-tahapan pada penelitian tindakan tersebut dilakukan berulang-ulang dan berkesinambungan sampai pada tahapan yang hasilnya telah memenuhi target pada indikator keberhasilan.

Penelitian tindakan kelas (PTK) bertujuan mengenali masalah pembelajaran, menemukan pemecahan masalah pembelajaran yang aktual dengan mengembangkan inovasi pembelajaran, untuk: meningkatkan mutu isi, masukan, proses, dan hasil pembelajaran; mengatasi masalah pembelajaran secara terencana dan berkelanjutan; meningkatkan kerja sama profesional antara pendidik di semua jenjang pendidikan; menumbuhkembangkan budaya akademik dan profesionalisme di kalangan pendidik sehingga tercipta sikap proaktif dalam memperbaiki mutu pembelajaran secara berkelanjutan.

Manfaat dari PTK adalah Meningkatkan kompetensi guru dalam mengatasi masalah pembelajaran di kelas; Memberdayakan dan memanfaatkan hasil kerja kreatif dosen semaksimal mungkin; Mengaktualisasikan potensi siswa untuk mencapai hasil belajar yang maksimal; Menumbuhkembangkan budaya inovasi guru dalam mengembangkan model dan perangkat pembelajaran di sekolah; Meningkatkan produktivitas publikasi ilmiah guru; dan Meningkatkan koloborasi antarguru dalam memecahkan masalah pembelajaran di kelas.

PTK sering disalahkaprahkan dengan Penelitian Eksperimen karena sama-sama memberikan perlakuan (treatment) pada peserta didik. Perbedaan yang mendasar antara PTK dan Penelitian Eksperimen terletak pada tujuan yang ingin dicapai. Penelitian Eksperimen bertujuan untuk menguji tindakan, sedangkan PTK bertujuan untuk menyelesaikan masalah pembelajaran. Penelitian Eksperimen mengenal istilah populasi dan sampel, sedangkan PTK, karena bertujuan untuk menyelesaikan permasalahan dalam konteks tertentu dan terbatas, tidak ada istilah populasi dan sampel. tetapi digunakan istilah 'subyek penelitian'. Karena prosedur itu, maka hasil Penelitian Eksperimen dapat digeneralisasi dari sampel ke populasi, sedangkan hasil PTK hanya berlaku untuk kelas yang dikaji saja, kecuali kelas lain memiliki karakteristik yang hampir sama dengan kelas yang diteliti.

Sebagai sebuah kajian ilmiah, PTK harus dirancang dengan langkah-langkah/prosedur ilmiah dan sistematis. Langkah-langkah dalam penyusunan PTK adalah sebagai berikut: Analisis dan Penetapan Fokus Masalah penelitian; Penentuan Solusi/Tindakan perbaikan; Perumusan Masalah Penelitian; Penetapan Judul; Perumusan Tujuan dan Manfaat Hasil penelitian; Perumusan Hipotesa Tindakan; dan Perencanaan Tindakan.

Kegiatan pendampingan penyusunan Proposal PTK ini telah menghasilkan 11 draf Proposal PTK yang siap untuk dikembangkan menjadi Proposal PTK. Draf Proposal PTK tersebut diperoleh berdasarkan jawaban peserta dalam menyelesaikan 10 tugas pada Lembar Kerja. Berikut ini disajikan 11 judul proposal PTK yang berhasil disusun oleh peserta.

1. Meningkatkan Keaktifan Dan Penguasaan Keterampilan Siswa Dalam Mengembangkan Ragam Gerak Tari Tradisi Pada Siswa Kelas X.

2. Meningkatkan Kemampuan Membaca AlQur'an dengan Metode Card Short Kelas X SMA Negeri 2 Gerung.

3. Peningkatan Hasil Belajar Siswa dalam Materi Pembuktian Identitas Trigonometri dengan Menggunakan Metode Scaffolding Kelas X SMA Negeri 2 Gerung TP 2019/2020.

4. Meningkatkan Hasil Belajar Siswa pada Materi Termokimia Kelas XI dengan Menggunakan Metode STAD.

5. Meningkatkan Partisipasi Siswa Menggunakan Metode Pembelajaran Bermain Peran di Kelas X IPS SMA Negeri 2 Gerung.

6. Peningkatan Minat Membaca pada Siswa Kelas $\mathrm{X}$ dengan Melakukan Literasi yang Bervariatif.

7. Meningkatkan Pemahaman Konsep Siswa tentang Sel Menggunakan Media LCD pada Proses Praktikum.

8. Meningkatkan Minat Baca Siswa Melalui Pemberian Tugas Membuat Cerita Rakyat Bergambar. 
9. Meningkatkan Keterampilan Berbicara Menggunakan Bahasa Inggris Siswa Melalui Kegiatan Study Tour ke Tempat Wisata.

10. Peningkatan Kemampuan Speaking Siswa dengan Menggunakan Metode Clustering.

11. Media Gadget di Rumah Belajar dapat Meningkatkan Minat dan Hasil Belajar Fisika Siswa Kelas XII SMA Negeri 2 Gerung.

Pada akhir kegiatan pengabdian kepada masyarakat ini, peserta diberikan Lembar Evaluasi Kegiatan Pendampingan sehingga didapatkan informasi tentang 4 aspek positif yang diperoleh peserta yaitu bahwa: pertama, guru-guru memiliki pengetahuan yang lebih tentang penyusunan Proposal PTK sehingga lebih mudah bagi guru dalam menyusun draf Proposal PTK; kedua, kegiatan pengabdian kepada masyarakat dalam bentuk pendampingan telah mampu menghasilkan produk draf Proposal PTK; ketiga, kegiatan pengabdian ini telah memberikan motivasi bagi guru dalam menyusun Proposal PTK; keempat, pendampingan penyusunan Proposal PTK membantu guru mempermudah langkah untuk pengusulan kenaikan pangkat.

\section{Kesimpulan}

Kegiatan pendampingan penyusunan proposal PTK ini telah meningkatkan kompetensi profesionalisme guru di SMA Negeri 2 Gerung. Hal ini ditunjukkan dengan banyaknya aspek positif yang diperoleh dari kegiatan pendampingan. Kegiatan pendampingan penyusunan Proposal PTK ini telah menghasilkan 11 draf Proposal PTK.

\section{Saran}

Kegiatan pendampingan ini telah menghasilkan draf Proposal PTK berdasarkan 10 tugas yang terdapat pada Lembar Kerja. Draf Proposal PTK yang berhasil disusun perlu disempurnakan sehingga menghasilkan Proposal PTK yang lebih baik dan siap untuk pelaksanaan PTK di kelas. Dengan demikian, diperlukan alokasi waktu pendampingan yang lebih lama untuk penyempurnaan proposal dan untuk pelaksanaan PTK.

\section{Ucapan Terima Kasih}

Penulis mengucapkan terima kasih kepada Universitas Mataram yang telah memberi dukungan financial terhadap kegiatan pengabdian kepada masyarakat ini.

\section{Daftar Pustaka}

Aqib, Z. 2009. Penelitian Tindakan Kelas. Bandung: Yrama Widya.

Aries, E.F. 2010. Design Action Reserch. Malang: Aditya Media Publishing.

Kusnandar. 2008. Langkah Mudah Penelitian Tindakan Kelas Sebagai Pengembangan Profesi Guru. Jakarta: Raja Grafindo Persada.

Sujana, I, M., dan Muntari. 2012. Modul PLPG: Penelitian Tindakan Kelas dan Karya Ilmiah. Mataram: Panitia Sergur Rayon 122 Universitas Mataram. 